\title{
Correlation of water's physico-chemical characteristics and trematode parasites of Channa punctata (Bloch) in Awangsoi lake, M anipur, India
}

\author{
Huidrom Puinyabati ${ }^{*}$, M aibam Shomor endr ${ }^{2}$ and Devashish $\mathrm{K}$ ar ${ }^{1}$ \\ ${ }^{1}$ Division of Wetlands, Fishery Science and Aquaculture, Department of Life Science and Bioinformatics, Assam \\ (Central) University, Silchar-11 (Assam), INDIA \\ ${ }^{2}$ Fish disease Research Lab, Department of Zoology, Thambal Marik College, Oinam- 795134 (Manipur), INDIA \\ *Corresponding author. E-mail: hpuinya @ rediffmail.com \\ Received: February 6, 2013; Revised received: April 22, 2013; Accepted: M ay 5, 2013
}

Abstract: Infection with trematode parasites can lead to severe change in nutrient content and may result in host mortalities and character of a water body may influence the parasitic fauna. Hence a study was carried out from 2010 to 2011 to find out a correlation of water's physic-chemical characteristics and trematode parasites of Channa punctata (Bloch) in Awangsoi Lake, Manipur, India. During the present investigation three species of trematodes were recorded. In the present study there were concurrent infections by two or more parasite species. The percentage of infection was positively correlated with temperature, $\mathrm{pH}, \mathrm{DO}$ and conductivity in Awangsoi Lake. There was a significant positive correlation $(r=0.652 ; p<0.05)$ with $\mathrm{FCO}_{2}$ and a negative correlation with alkalinity. Seasonal variation in the occurrence of these parasites may be attributed to ecological conditions, particularly distribution of intermediate hosts and also the age of the host and the life cycle of the parasite species.

Keywords: Awangsoi Lake, Channa punctata, Physico-chemical parameters, Trematodes

\section{INTRODUCTION}

The physico-chemical parameters of a water body have been recognized as valuable limiting factors in the biological productivity of water body. Maintenance of a healthy aquatic ecosystem is dependent on physicochemical parameters of water. The nature of parasitisation of fish population in any confined body of water is affected by a variety of factors. Wisniewski (1958) formulated the concept of the characterization of parasitofauna and further suggested that the character of a water body could be used to influence and determine the parasitic fauna. The nature of parasitisation of fish population in any confined body of water is affected by a variety of biotic and abiotic factors. Some of the abiotic factors are temperature, $\mathrm{pH}, \mathrm{DO}$ content, alkalinity etc. Gaffar (2007) observed that the effect of temperature on the fishes is an important factor for infestation rate of parasites. Aquatic organisms are affected by $\mathrm{pH}$ because most of their metabolic activities are $\mathrm{pH}$ dependent (Wang et al., 2002).Unfortunately the knowledge of disease of the fishes, particularly parasites are still less explored in Manipur. Hence, a study on correlation of water's physico-chemical characteristics and trematode parasites of Channa punctata (Bloch) in Awangsoi Lake, Manipur has been undertaken.

\section{MATERIALS AND METHODS}

The present study was carried out in Awangsoi Lake of
Manipur which is situated between $24^{\circ} 39^{\prime} 48^{\prime \prime} \mathrm{N}$ $24^{\circ} 39^{\prime} 23^{\prime \prime} \mathrm{N}$ latitude and $93^{\circ} 47^{\prime} 04^{\prime \prime} \mathrm{E}-93^{\circ} 46^{\prime} 90^{\prime \prime} \mathrm{E}$ longitude about $24 \mathrm{~km}$. from Imphal. The fish C. punctata were routinely collected from the study sites (from 20102011) and brought to the laboratory in the polythene bags containing water of the same locality. The external body organs as well as internal body organs were thoroughly examined for the parasites. Mucus and epithelial tissue was scraped from several areas of the body with a scalpel. The mucus material is then transferred to a small drop of water on a slide and covered with a small size coverglass. The scraping was thin enough for proper examination with the microscope. Epithelial scrapings from the fins were made and subjected to microscopic examination. For examination of the gills, each branchial arch was removed and transferred to a petridish with water. The examination was performed under microscope. Branchial filaments were cut off, slightly compressed in a drop of water between slide and coverglass and examined under the microscope. The oral cavity and pharynx were examined macroscopically. The digestive canal was first examined for macroscopic parasites located on the external surface, and then stretched on the dish and carefully opened. The gut content was removed, diluted to some extent with physiological saline and was examined macroscopically and under the microscope. Liver, kidney, gonads and heart were examined externally and also under a compound 
microscope. These organs were cut with a scalpel into slices and the section surfaces were examined. Small tissue samples were compressed under coverglass and were examined under a microscope. The parasites collected, upon being fully relaxed, were fixed in AFA (alcohol-formalin-acetic-acid) solution and preserved in $70 \%$ alcohol. To facilitate identification of the worms, the trematodes were stained in Alum carmine, dehydrated in glacial acetic acid, cleaned in methyl salicylate and mounted in Canada balsam (Bylund et al., 1980). The physico-chemical parameters of water were analyzed following APHA (2005).

\section{RESULTS AND DISCUSSION}

The present study was carried out from February'10January' 11 for seasonal study of parasites with physicochemical characteristics of water. During the present investigation three species of trematodes have been found namely M etaclinostomum sp. Pandey and Baugh, Genarchopsis goppo Ozaki and Allocreadium fasciatusi Kakaji and there were concurrent infections by two or more parasite species. M etaclinostomum sp. was found to be infected in the liver of the fish and G. goppo and A. fasciatusi were found in the intestine.

The correlation matrix among physico-chemical properties and prevalence ( $\%$ of infection) is given in Table 1 . The seasonal variation of percentage of infection with physico-chemical parameters of water in Awangsoi Lake is indicated in Fig.1. In the present study, the maximum percentage of infection (65.38) was found in November at water temperature $22^{\circ} \mathrm{C}, \mathrm{pH}-6.4$, DO-6.2 mg/l, $\mathrm{FCO}_{2}-7 \mathrm{mg} / \mathrm{l}$, alkalinity- $30 \mathrm{mg} / \mathrm{l}$ and conductivity-128 $\mu$ Mho in Awangsoi Lake.

The percentage of infection was positively correlated with temperature, $\mathrm{pH}, \mathrm{DO}$ and conductivity in Awangsoi Lake. There was a significant positive correlation $(\mathrm{r}=$ $0.652 ; \mathrm{p}<0.05$ ) with $\mathrm{FCO}_{2}$ and a negative correlation with alkalinity.

High significant positive relationship of temperature with $\mathrm{FCO}_{2}(\mathrm{r}=0.610 ; \mathrm{P}<0.05)$ was found in Awangsoi Lake. Water temperature in Awangsoi showed negative correlation with $\mathrm{pH}$ and positive correlation with $\mathrm{DO}$, alkalinity and conductivity. $\mathrm{pH}$ showed positive correlations with temperature, $\mathrm{DO}, \mathrm{FCO}_{2}$ and conductivity and negative correlation with alkalinity. DO showed high significant negative correlation $(\mathrm{r}=-0.624 ; \mathrm{P}<0.05)$ with alkalinity. It showed positive correlations with temperature, $\mathrm{FCO}_{2}$ and conductivity and negative correlation with $\mathrm{pH}$.

Ecological factors have been held widely responsible for the occurrence of adult digenetic trematodes quoted from Chubb (1979) and Madhavi (1978). Aquatic organisms are affected by $\mathrm{pH}$ because most of their metabolic activities are $\mathrm{pH}$ dependent (Wang et al., 2002). Optimal

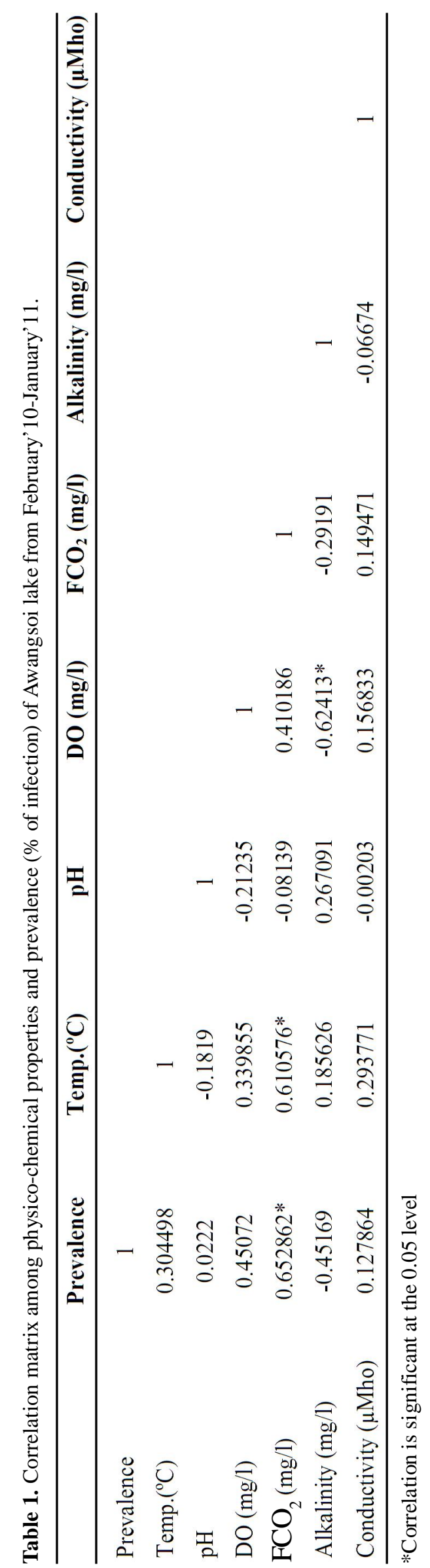




\section{$\%$ of infection with different temperatures}

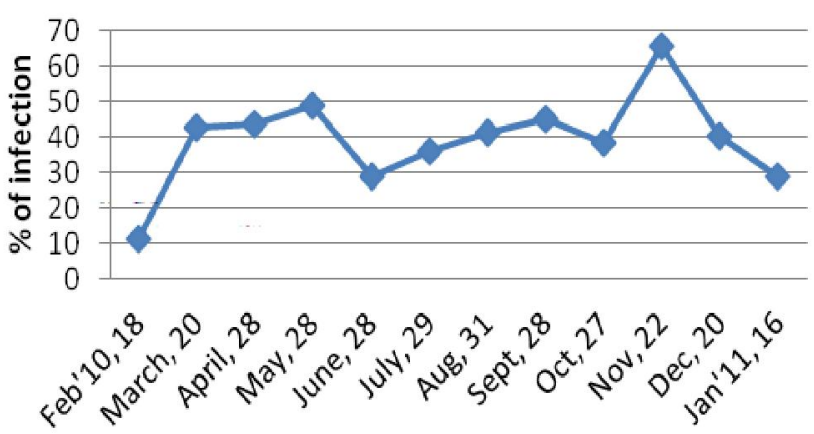

Different temperature $\left({ }^{\circ} \mathrm{C}\right)$

\section{$\%$ of infection with different DO}

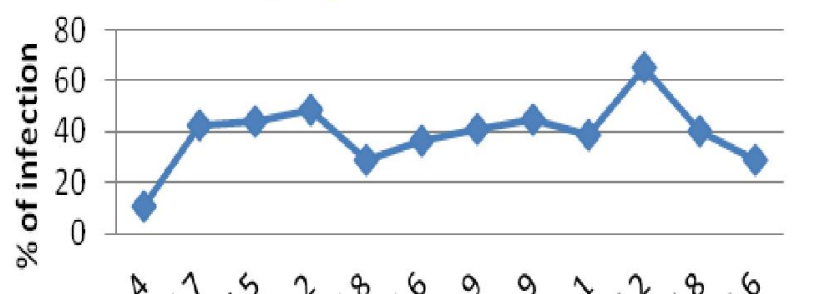

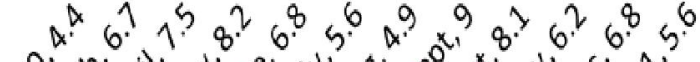

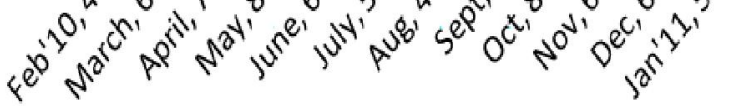

$\mathrm{DO}(\mathrm{mg} / \mathrm{l})$

\section{$\%$ of infection with alkalinity}

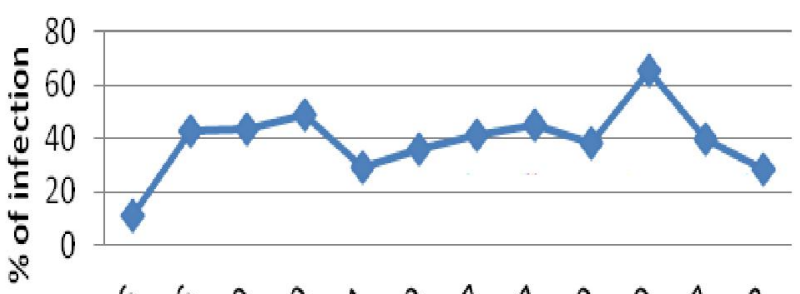

8

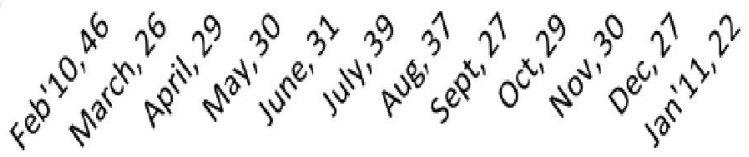

Alkalinity (mg/l)
$\%$ of infection with different $\mathrm{pH}$

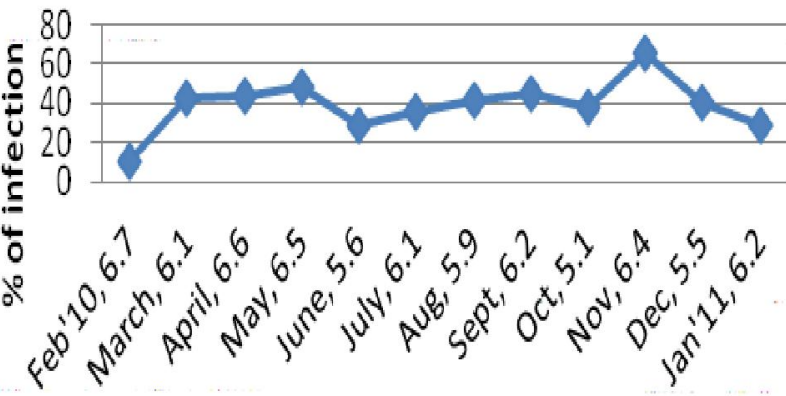

Different pH values

\section{$\%$ of infection with $\mathrm{FCO}_{2}$}
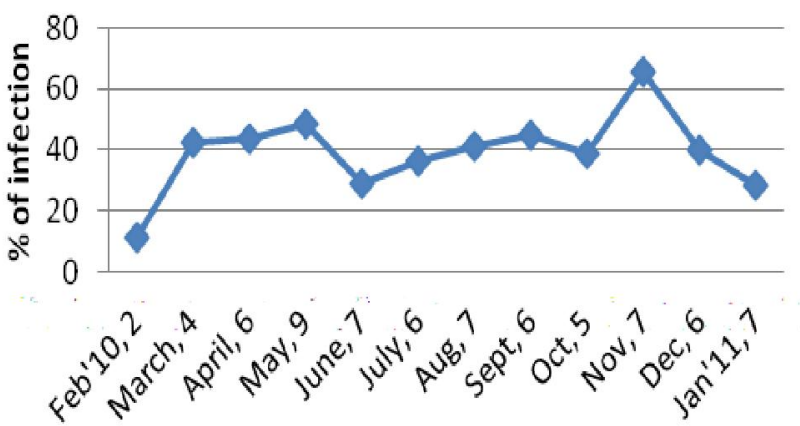

$\mathrm{FCO}_{2}(\mathrm{mg} / \mathrm{l})$

\section{$\%$ of infection with conductivity}

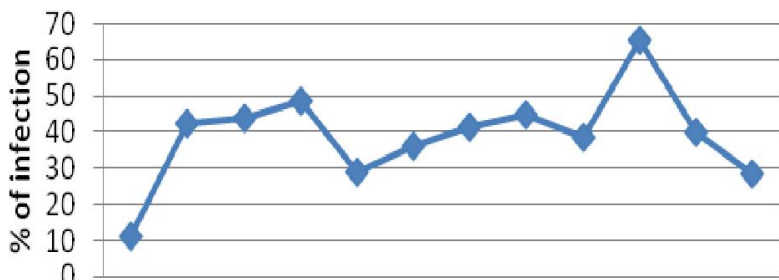

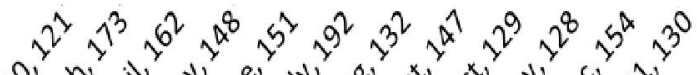

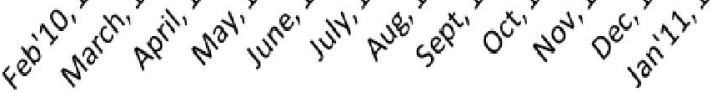

Conductivity (uMho)

Fig. 1. Seasonal occurrence of parasites with physico-chemical properties in Awangsoi Lake.

$\mathrm{pH}$ range for sustainable aquatic life is $\mathrm{pH} 6.5-8.2$ (Murdoch et al., 2001). Pawar and Pulle (2005) stated that the $\mathrm{pH}$ of water is important for biotic communities because most of the plant and animal species can survive in narrow range of $\mathrm{pH}$ from slightly acidic to slightly alkaline condition. In the present study the water of Awangsoi Lake showed slightly acidic condition.

Tedila and Fernando (1970) discussed that fish become infected in autumn and incidence peaked late in winter, began to decrease in March dropped to nit in AugustSeptember. Gaffar (2007) observed that the effect of temperature on the fishes is an important factor for infestation rate of parasites. He found high infestation rate in the hot season. The same has also been reported by Bussmann and Ehrich (1979), Amin (1987) and Fatima and Bilqees (1989).

Chubb (1982) emphasized that water temperature acts directly on the helminths or indirectly through the host behaviour, especially feeding behaviour and metabolism, while, Jha et al. (1992) showed that water temperature did not play an important role in the seasonal occurrence of helminth parasites.

During the present study concurrent infections by two or more parasite species were found. The percentage of 
infection was positively correlated with temperature, $\mathrm{pH}$, DO and conductivity in Awangsoi Lake. There was a significant positive correlation $(r=0.652 ; \mathrm{p}<0.05)$ with $\mathrm{FCO}_{2}$ and a negative correlation with alkalinity. Seasonal variation in the occurrence of these parasites may be attributed to ecological conditions, particularly distribution of intermediate hosts and also the age of the host and the life cycle of the parasite species. The results also give preliminary knowledge of parasitic fauna of fish C. punctata from Manipur which was till date less explored. At the same time it will help the scientific community and also pisciculturists to know about the parasite species found to be infected in the fish host.

\section{ACKNOWLEDGEMENT}

The authors are thankful to the Head, Department of Life Science and Bioinformatics, Assam University, Silchar and Principal, Thambal Marik College, Oinam, Manipur for giving laboratory facilities. Thanks are due to Prof. Umapati Sahay, the former Head of the Dept. of Zoology and Dean, faculty of Science, Ranchi University, Ranchi and Dr. Rajendra Prasad, Head of the Dept. of Zoology, Marwari College, Ranchi for helping in identification of the specimens and providing necessary laboratory facilities.

\section{REFERENCES}

Amin, O.M. (1987). Acanthocephala from lake fishes in 'Wisconsin: Ecology and host relationships of Pomphorhynchus bulbocolli (Pomphporhynchidac). J . Parasitol., 73: 278-289.

APHA (2005). Standards methods for the eaxamination of water and wastewater. American Public Health Association, Washington.

Bussmann, B. and Ehrich, S. (1979). Investigations on infection of blue whiting (M icromesistius poutassou) with larval Anisakis sp. (Nematoda : Ascaridida). Arch. Fischereiwiss., $29: 155-165$.
Bylund, G., Fagerholm, H.P., Calenius, G., Wikgreen, B.J. and Wikstrom, M. (1980). Parasites of fish in Finland - ii. Methods for studying parasite fauna in fish. Acta Acad. Aboenisis, 40(2): 1-23.

Chubb, J.C. (1979). Seasonal occurrence of helminth parasite in fishes. Part-II. Trematoda. Advances in Parasitology, 17 171-313.

Chubb, J.C. (1982). Seasonal occurrence of helminth parasite in fishes. Part-IV. Adult cestoda, nematoda and acanthocephala. Advances in Parasitology, 20: 1-292.

Fatima, H. and Bilqees, F.M. (1989). Seasonal variation of nematodes and acanthocephala of some fishes of Karachi coast. Proc. Parasitol., 7\&8: 1-201.

Gaffar, R.A. (2007). Seasonal variation and histopathology of helminth parasites in the fish Lutianus argentimaculatus (Forsk, 1775) red snapper. Ph.D. thesis, University of Karachi, Pakistan, p. 705.

Jha, A.N. , Sinha, P. and Mishra, T.N. (1992). Seasonal occurrence of helminth parasites in fishes of Sikandarpur reservoir, Muzzaffarpur (Bihar). Indian J. H elminth., 44(1): 1-8.

Madhavi, R. (1978). Life history of G enar copsis goppo Ozaki, 1925 (Trematoda: Himiuridae) from freshwater fish Channa puntatus. J . Helminth., 52: 251-259.

Murdoch, T., Cheo, M. and O'Laughlin, K. (2001). Streamkeeper's Field Guide: watershed inventory and stream monitoring methods. Adopt-A-Stream Foundation, Everett, WA.

Pawar, S.K. and Pulle, J.S. (2005). Studies on physico-chemical parameters in Pethwadaj dam, Nanded district in Maharastra. India. J. Aqua. Bio., 20(2): 123-128.

Tedila, S. and Fernando, C.H. (1970). Some remarks on the ecology of echinorhynchus salmonis (Muller, 1784). Cad. J. Zool., 48: 317-321.

Wisniewski, L.W. (1958). Observation of the parasito fauna of an eutrophic lake (Parasito fauna of biocoenosis of Druzno lake, Part I). Acta Parasite.Pol., 6: 1-64.

Wang, W., Wang, A. , Chen, L., Liu, Y. and Sun, R. (2002). Effects of $\mathrm{pH}$ on survival, phosphorus concentration, adenylate energy charge and $\mathrm{Na}^{+} \mathrm{K}^{+}$ATPase activities of Penaeus chinensis osbeck juveniles. Aquatic Toxicology, 60: 75-83. 